\title{
CULTIVATION OF OYSTER MUSHROOM (Pleurotus spp.) USING FERMENTATION SUBSTRATE
}

\author{
Nguyen Hoang Mai ${ }^{\mathrm{a}}$, Truong Binh Nguyen ${ }^{{ }^{*}}$, Phan Hoang Dai ${ }^{\mathrm{a}}$, Le Ba Dung \\ ${ }^{a}$ The Institute of Research and High-tech Application in Agriculture, Dalat University, Lamdong, Vietnam \\ ${ }^{b}$ The Faculty of Biology, Dalat University, Lamdong, Vietnam \\ *Corresponding author: Email: nguyentb@dlu.edu.vn
}

Article history

Received: December $18^{\text {th }}, 2018 \mid$ Accepted: February $27^{\text {th }}, 2019$

\begin{abstract}
This study was carried out on the cultivation of five species of Pleurotus using fermentation substrate. Paddy (Oryza sativa) was used for spawn production. Five species of Pleurotus (identified and selected in the isolation process from mushroom farms in Lamdong province) with prepared compost were examined for time of spawn running, infection rate and biological efficiency. The experiment was set up as a completely randomized design with three replicates. Pleurotus hybrid (P. hybrid) and Pleurotus sajor-caju ( $\underline{P}$. sajor-caju) had good growth potential on compost. It took about 21 days for the mycelium to spread completely through the substrate $(5 \mathrm{~kg}$ per bag). However, $\underline{P}$. abalonus, $\underline{P} . \underline{\text { citrinopileatus, }}$ and $\underline{P}$. djamor did not grow well on fermentation substrate. In this study, although the inoculation was not conducted under sterile conditions, fungal infections were not present $(0 \%)$ and the biological efficiency exceeded $62 \%$ (P. hybrid attained $62.68 \pm 9.13 \%$ and $\underline{P}$. sajor-caju $62.82 \pm 7.56 \%$ ).
\end{abstract}

Keywords: Compost; Cultivation; Fermentation substrate; Oyster mushroom; Pleurotus spp.; Spawn.

DOI: http://dx.doi.org/10.37569/DalatUniversity.9.2.539(2019)

Article type: (peer-reviewed) Full-length research article

Copyright (C) 2019 The author(s).

Licensing: This article is licensed under a CC BY-NC-ND 4.0 


\section{NUÔI TRỒNG NẤM BÀO NGƯ (Pleurotus spp.) BẦNG CƠ CHẤT LÊN MEN}

\section{Nguyễn Hoàng Mai ${ }^{a}$, Trương Bình Nguyên ${ }^{a^{*}}$, Phan Hoàng Đạia ${ }^{a}$ Lê Bá Dũngb}

${ }^{a}$ Viện Nghiên cứu và Úng dụng Nông nghiệp Công nghệ cao, Truờng Đại học Đà Lạt, Lâm Đồng, Việt Nam

${ }^{b}$ Khoa Sinh học, Truòng Đại học Đà Lạt, Lâm Đồng, Việt Nam

"Tác giả liên hệ: Email: nguyentb@dlu.edu.vn

\section{Lịch sử bài báo}

Nhận ngày 18 tháng 12 năm 2018 | Chấp nhận đăng ngày 27 tháng 02 năm 2019

\section{Tóm tắt}

Nghiên cứu được thực hiện nhằm đánh giá khả năng nuôi trồng năm loài nấm Pleurotus trên co chất lên men. Hạt thóc (Oryza sativa) được sủ dụng để làm giống sản xuất. Năm loài Pleurotus (được định danh và tuyển chọn trong quá trình phân lập tù các trại nấm trong phạm vi tỉnh Lâm Đồng) được cấy vào compost, quá trình nuôi trồng được theo dõi và đánh giá qua các thông số: Thời gian mọc kín co chất, tỷ lệ nhiếm bệnh, và hiệu suất sinh hoc. Các thí nghiệm được thực hiện hoàn toàn ngẫu nhiên và được lặp lại ba lần. Kết quả cho thấy các loài P. hybrid và $\underline{P}$. sajor-caju có tiềm năng sinh truởng và phát triển tốt trên co chất lên men. Sọi nấm mọc kín hoàn toàn cơ chất (túi nilon chứa $5 \mathrm{~kg}$ ) trong khoảng 21 ngày. Tuy nhiên, cũng theo kết quả thu được, ba loài nấm $\underline{P}$. abalonus, $\underline{P}$. citrinopileatus, và $\underline{P}$. djamor, không phù hợp để nuôi trồng trên co chất lên men. Trong nghiên cứu này, mặc dù quá trình cấy giống không được tiến hành trong điều kiện vô trùng, nhung không ghi nhận hiện tuợng nhiếm khuẩn, nhiễm nấm mốc (tý lệ nhiếm là $0 \%$ ) và hiệu suất sinh hoc đạt trên $62 \%$ (P. hybrid đạt $62.68 \pm 9.13 \%$ và P. sajor-caju đạt $62.82 \pm$ $7.56 \%)$.

Từ khóa: Compost; Cơ chất lên men; Hệ sợi; Nấm bào ngư; Nuôi trồng; Pleurotus spp.

DOI: http://dx.doi.org/10.37569/DalatUniversity.9.2.539(2019)

Loại bài báo: Bài báo nghiên cứu gốc có bình duyệt

Bản quyền @ 2019 (Các) Tác giả.

Cấp phép: Bài báo này được cấp phép theo CC BY-NC-ND 4.0 


\section{INTRODUCTION}

Oyster mushroom is the common name for the mushrooms of the genus Pleurotus that consists of about 70 species, belonging to the Pleurotaceae family and distributed globally. In nature, the mushroom grows on dried or weakened tree trunks, forming interwoven mushrooms resembling stairs. Many of these mushrooms are native to the Mediterranean region of Europe, the Middle East and North Africa but are now grown throughout Asia. Since the 1970s, oyster mushrooms have been one of the most commonly cultivated edible mushrooms in the world. This mushroom is quite easy to grow and has high biological efficiency compared to other cultivated mushrooms (Kong, 2004).

Currently, in some developed countries, some species of Pleurotus are being cultivated on an industrial scale bringing about great economic benefits, such as Pleurotus ostreatus, Pleurotus abalonus, Pleurotus citrinopileatus, Pleurotus djamor, Pleurotus sajor-caju, and Pleurotus eryngii. In order to cultivate successfully and efficiently, it is important to have a thorough understanding of the culture requirements. According to a review by Stamets (1993), species of Pleurotus genus differ in biological characteristics, growth and development conditions, especially fruiting temperature. For example, low temperature mushrooms such as $P$. ostreatus, the ideal temperature for growing mycelium is from 25 to $27^{\circ} \mathrm{C}$ but for fruiting is from 15 to $21^{\circ} \mathrm{C}$. In addition, some species, such as $P$. pulmonarius, are suitable for high temperature fruiting conditions, from 18 to $24^{\circ} \mathrm{C}$. However, fruit body formation in some species, such as $P$. sajor-caju, can be over a wide range of temperature and some can grow even at $30^{\circ} \mathrm{C}$. Farmers often utilize the biological characteristics of different species to grow them in suitable geographic areas so the cost of farming will be greatly reduced. Many processes of cultivating the Pleurotus species have been developed based on these properties. In fact, even in the same species, different cultivars require different culture conditions.

Generally, mushroom species can be cultivated in two ways. Firstly, using composted substrates: Wheat and rice straw, corn cobs, hay, water hyacinth, composted manure, and various other agricultural by-products including coffee husks and banana leaves. Secondly, using woody substrates: Logs or sawdust (Marshall \& Nair, 2009).

In mushroom production, composting is a basic process that prepares nutritional materials for the growth of mushrooms. The principle of this method is to use the fermentation of aerobic microorganisms such as Actinomyces spp. and Humicola spp., to ferment sources that are high in cellulose and lignin (nutritional supplements). Thus, the fermentation process not only produces a nutrient source for growing mushrooms but also creates a substrate that is more beneficial for mushrooms growth than other microorganisms. That is the reason why mushrooms can be cultured under ex-vitro conditions without being infected by fugal pathogens, such as Tricoderma spp., Mucor spp., and Pseudomonas spp. (Vedder, 1978).

Growing oyster mushrooms on fermented substrates has been studied and implemented in some developed countries, such as Japan, Korea, and Germany. In 
simpler terms, the material used for mushroom cultivation is fiber, such as waste cotton, rice straw, corn stalks, and so on. The substrate is moistened and mixed with some nutrients from rice bran, soybean meal, etc., depending on the appropriate $\mathrm{C} / \mathrm{N}$ ratio for each species (Choi, 2004). After fermentation, spawn mushrooms are inoculated to the substrate under ex-vitro conditions in a certain proportion which is often much larger than for in-vitro culture (Rajarathnam \& Bano, 1987). According to previous authors, cultivating mushrooms by this method often leads to higher productivity and shorter mushroom harvest times (Choi, 2004). However, the biggest disadvantage of this method is that it is very difficult to control disease. Especially, the less experienced growers often have trouble in the fermentation stage. In fact, not all Pleurotus species can grow well on a fermentation substrate. Some species of oyster mushroom are weakly competitive with microorganisms or have slow growth rates that are often unsuitable for this cultivation method (Rajarathnam \& Bano, 1988).

The Central Highlands and central provinces of Vietnam have a huge source of raw materials such as straw, bagasse, and corn husks. After harvesting, these byproducts are often wastefully burned and contaminate the environment instead of being well exploited by being used in mushroom cultivation to achieve high economic efficiency. On the other hand, oyster mushroom growing methods in our country are not suitable for these materials. The method that we propose can effectively make use of long fiber materials in the cultivation of mushrooms. The aim of this study is to select some species of Pleurotus in our province that can be successfully cultivated on fermented substrates.

\section{MATERIAL AND METHODS}

\subsection{Fungal material}

Five species of Pleurotus (collected from Donduong, Ductrong, and Lacduong in Lamdong province) were isolated and maintained on potato glucose agar (PGA) at the Institute of Research and High-tech Application in Agriculture, Dalat University.

\subsection{Spawn preparation}

Paddy was cleaned manually to remove dust, debris, and impurities. After being cleaned, it was boiled in water until completely cooked, then be soaked for 15 minutes without heating. The excess water in paddy was drained off, then the cooled paddy was mixed with $0.5 \%$ calcium carbonate $\left(\mathrm{CaCO}_{3}\right)$ (compared to weight after cooking). The prepared paddy was poured into polypropylene bags (350g per bag) and autoclaved for 50 minutes at $121^{\circ} \mathrm{C}, 1 \mathrm{~atm}$. After sterilization, the bags were inoculated with bits of agar medium colonized with mycelium and then incubated at $22-24^{\circ} \mathrm{C}$ in a dark place. The mycelium grow and completely spread through the paddy in about 10 days.

\subsection{Substrate preparation}

Rice and cotton straw were soaked in water, to which was added $1 \%$ lime (compared with dry weight). The soaked substrate was mixed with $3 \%$ rice bran 
(compared to dry weight) and built into a pile of size $1.7 \mathrm{~m} \times 5 \mathrm{~m} \times 2.5 \mathrm{~m}$ in $9-12$ days. Main fermentation was considered complete when the mixture turned dark brown and sweet smelling, the straw became soft and pliable, the raw ingredients were capable of holding water, and the moisture content of the compost was from $68-74 \%$. After that, secondary fermentation started with pasteurization to kill bacteria, weed seeds and to remove the ammonia. Compost was delivered to a special room for a pasteurization period of 6 hours at $60^{\circ} \mathrm{C}$ on the second day. The process continued with a circulation fan to add oxygen and maintain the temperature above $40^{\circ} \mathrm{C}$ over the next few days. On the $7^{\text {th }}$ day, the fan reduced the temperature down to $35^{\circ} \mathrm{C}$. Then the substrate was ready for growing mushrooms.

\subsection{Substrate inoculation}

The substrate was inoculated by mixing with spawn at a rate of 5\%, filled into polypropylene bags ( $5 \mathrm{~kg}$ per bag) and incubated at $24^{\circ} \mathrm{C}$ for two weeks in a dark place. Once the bags were fully colonized, they were hung in a mushroom house where the relative humidity was maintained above $85 \%$. The humidity was maintained by frequent spraying of water on the bags and on the floor. Seven days after opening the bags, the mushroom pins appeared on the surface of substrate.

\subsection{Cropping and harvesting}

During pinning and fruit body development, a high relative humidity and proper ventilation was maintained in the mushroom house. Mushrooms were picked per day in the $3^{\text {rd }}$ or $4^{\text {th }}$ flush.

\subsection{Statistical analysis}

The data were analyzed using the Microsoft Excel 2016 (descriptive statistics) statistical formula for calculating $95 \%$ confidence intervals.

\section{RESULTS AND DISCUSSION}

\subsection{Identification of specimens}

Specimen 1: Pileus fan-shaped or slightly rounded triangular, 50 - 120mm long $\mathrm{x}$ $100-160 \mathrm{~mm}$ wide, incurvate margin when young, then convex, wavy with age, dark brownish grey to light brownish grey, cover with fine soft hair at centre, sometimes with radial ridges or with appressed radial tiny scales towards margin. Pileate trama white, thin-to-moderately thick-fleshed. Lamellae crowded, decurrent. Stipe $50-110$ x 5 $22 \mathrm{~mm}$, eccentric to lateral, connate, solid, whitish, in upper part longitudinally striate, frequently tomentose. Stipe trama whitish. Identified as Pleurotus hybrid (Figure 1a).

Specimen 2: Basidiome solitary to imbricate, pleurotoid, very thick, fragile. Pileus $100-180 \mathrm{~mm}$ long x $70-90 \mathrm{~mm}$ wide, surface brown to blackish brown with tiny scales formed by surface cracking, more numerous toward the margin. Margin entire to eroded, decurved or plane. Stipe brown to grayish, almost lateral $30-120 \mathrm{~mm}$ long x 15 
- 40mm wide, tapered to the base. Context white, fleshy when fresh, compact, corky when dry. Lamellae furcating, sometimes anatomosing, cream to ochraceous. Identified as Pleurotus abalonus (Figure 1b).

Specimen 3: Pileus is rounded, $10-70 \mathrm{~mm}$ bright yellow, broad, planodepressed, fleshy, dry, covered with densely matted hairs at center, glabrescent at last, margin inflexed and entire. Lamellae white, crowded, decurrent. Several stipes coming from the bulbous, eccentric, cylindrical, $20-50 \mathrm{~mm}$ long, $2-7 \mathrm{~mm}$ thick, white, solid, fleshy to fibrous, tomentous. Identified as Pleurotus citrinopileatus (Figure 1c).

Specimen 4: Pileus 60 - 130mm long x 60 - 10mm wide, pinkish, lobe, straight to incurved margin, with some matted hairs on the surface. Pileat trama fleshy, thin and tough. Lamellae crowded, deeply decurrent, pinkish. Stipe 3 - 15mm long x $15-20 \mathrm{~mm}$ wide, eccentric, fasciculate, cylindrical, group in bundles, occasionally somewhat tapering towards base, solid, pink, tomentose. Context pinkish in pileus and stipe. Identified as Pleurotus djamor (Figure 1d).

Specimen 5: Basidiome small, pileus 30 - 75mm long x 24 - 70mm wide, fanshaped or slightly rounded, margin inflexed when young, then convex, undulate when age, moderate to thick flesh, brownish grey, frequently covered with fine, soft hairs at centre, sometimes with radial ridges or with appressed radial squamules towards margin. Lamellae crowded, decurrent. Stipe eccentric to lateral, concrescent, solid, whitish, longitudinally striate in upper part. Identified as Pleurotus sajor-caju (Figure 1e).

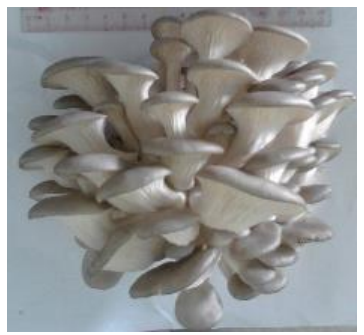

(a)

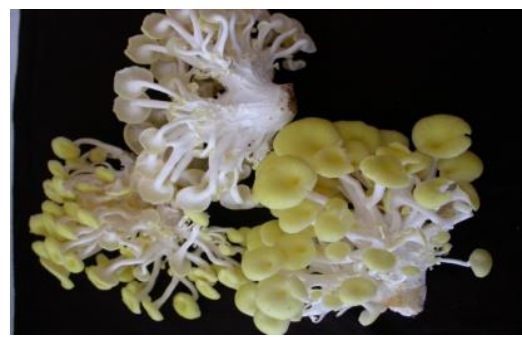

(c)

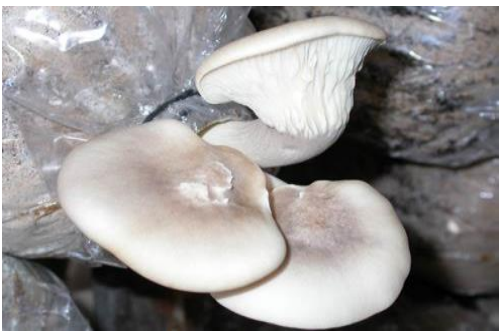

(b)

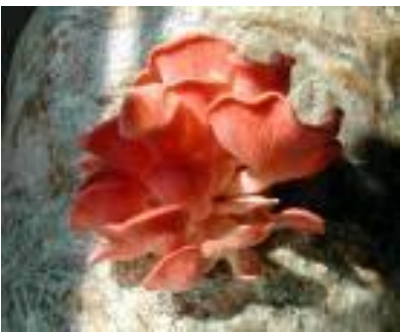

(d)

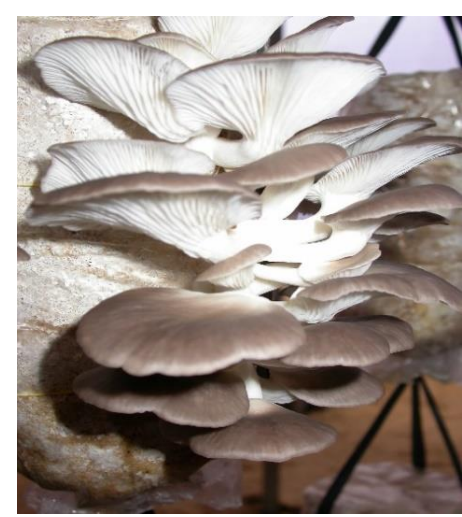

(e)

Figure 1. Five species of Pleurotus (identified and selected in the isolation process from mushroom farms in Lamdong province) 


\subsection{Cultivation Pleurotus spp. on fermentation substrate}

The results of the proximate analyses of the mushroom cultivated with compost are shown in Table 1. It shows that two species of Pleurotus (P. hybrid and P. sajorcaju) have good growth potential on compost. Although these two species have some differences in morphology (Figure 2), the growth rates of the mycelium and the biological productivity of the two strains were not significantly different. It took about 21 days for the mycelium to spread completely through the substrate (5kg per bag) $(P$. hybrid took $20.15 \pm 1.19$ days and $P$. sajor-caju took $20.89 \pm 1.30$ days). On the contrary, $P$. abalonus, $P$. citrinopileatus, and $P$. djamor did not grow well on the fermentation substrate. Many Pleurotus species can grow well on a sterile nutrient substrate but lack the ability to compete with fungal pathogens on a non-sterile substrate. In this study, although the inoculation was not conducted under sterile conditions, fungal infections were not present $(0 \%)$ and the biological efficiency reached above $62 \%$ ( $P$. hybrid attained $62.68 \pm 9.13 \%$ and $P$. sajor - caju $62.82 \pm$ $7.56 \%)$.

Table 1. Growth rate of mycelium of five species of Pleurotus on fermentation substrate

\begin{tabular}{llll}
\hline Species & Time of spawn running (days) & Infection rate (\%) & Biological efficiency (\%) \\
\hline P. hybrid & $20.15 \pm 1.19$ & 0 & $62.68 \pm 9.13$ \\
P. abalonus & 0 & 0 & 0 \\
P. citrinopileatus & 0 & 0 & 0 \\
P. djamor & 0 & 0 & 0 \\
P. sajor-caju & $20.89 \pm 1.30$ & 0 & $62.82 \pm 7.56$ \\
\hline
\end{tabular}

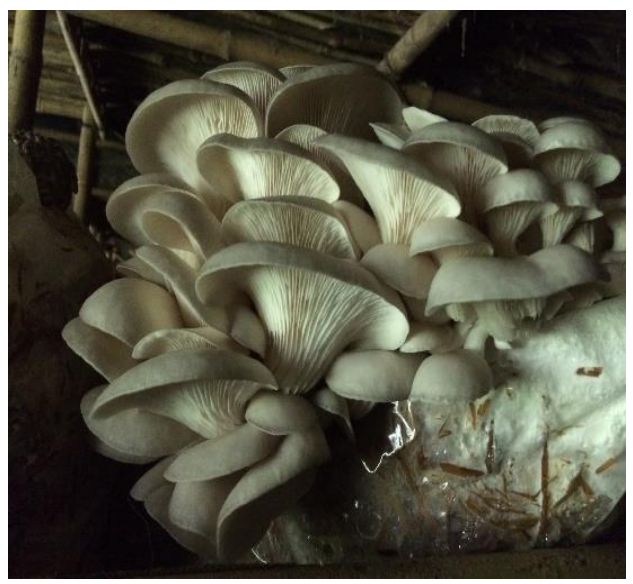

(a)

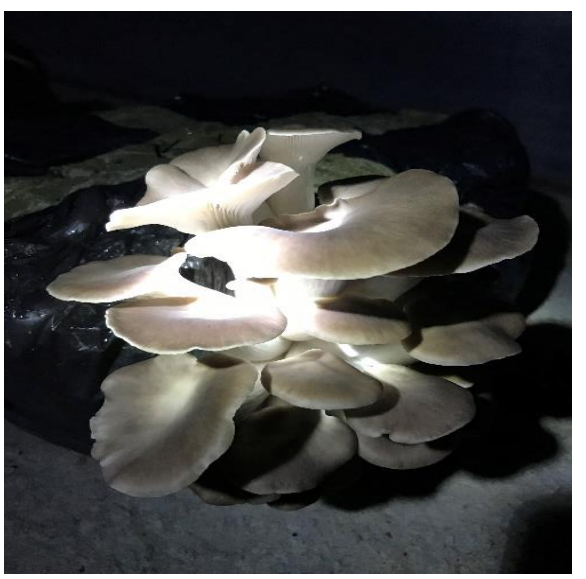

(b)

Figure 2. Two species of Pleurotus grow successful on fermentation substrate Notes: a) Pleurotus hybrid and b) Pleurotus sajor-caju. 


\section{CONCLUSION}

It can be concluded from the results of this study that two species of Pleurotus, Pleurotus hybrid and Pleurotus sajor-caju (selected in the isolation process from farms in Lamdong province) fully met the quality requirements for growing on a fermentation substrate in large scale mushroom farming.

\section{ACKNOWLEDGEMENTS} this study.

We express our sincere gratitude to the Dalat University for providing funds for

\section{REFERENCES}

Choi, K. W. (2004). Shelf cultivation of Oyster mushroom. In A. Evaristo et al. (Eds.), Oyster mushroom cultivation (pp. 167-179). Retrieved from http://www. fungifun.org/mushworld/Oyster-Mushroom-Cultivation/

Kong, W. S. (2004). Descriptions of commercially important Pleurotus species. In A. Evaristo et al. (Eds.), Oyster mushroom cultivation (pp. 54-61). Retrieved from http://www.fungifun.org/mushworld/Oyster-Mushroom-Cultivation/.

Marshall, E., \& Nair, N. G. (2009). Rural infrastructure and agro-industries division. Retrieved from http://www.fao.org/fileadmin/templates/ags/docs/flyers/AGS_ flyer_industry.pdf

Rajarathnam, S., \& Bano, Z. (1987). Pleurotus mushrooms. Part 1A: Morphology, life cycle, taxonomy, breeding, and cultivation. Critical Reviews in Food Science and Nutrition, 26(2), 157-223.

Rajarathnam, S., \& Bano, Z. (1988). Pleurotus mushrooms. Part 1B: Pathology, in vitro and in vivo growth requirements, and world status. Critical Reviews in Food Science and Nutrition, 26(3), 243-311.

Stamets, P. (1993). Growing gourmet and medicinal mushrooms. Hongkong, China: Ten Speed Press.

Vedder, P. J. C. (1978). Modern mushroom growing. London, UK: Stanley Thornes Publishing. 